This PDF is a selection from a published volume from the National Bureau of Economic Research

Volume Title: Innovation and Public Policy

Volume Authors/Editors: Austan Goolsbee and Benjamin Jones, editors

Volume Publisher: University of Chicago Press

Volume ISBNs: 978-0-226-80545-0 (cloth), 978-0-226-80559-7 (electronic)

Volume URL:

https://www.nber.org/books-and-chapters/innovation-and-public-policy

Conference Date: March 13, 2020

Publication Date: February 2022

Chapter Title: Immigration Policy Levers for US Innovation and StartUps

Chapter Author(s): Sari Pekkala Kerr and William R. Kerr

Chapter URL:

https://www.nber.org/books-and-chapters/innovation-and-public-policy/ immigration-policy-levers-us-innovation-and-start-ups

Chapter pages in book: p. $85-115$ 


\title{
Immigration Policy Levers for US Innovation and Start-Ups
}

\author{
Sari Pekkala Kerr and William R. Kerr
}

\subsection{Introduction}

US policy makers are always on the hunt for levers that can boost entrepreneurship and innovation. Especially in a time of declining business dynamism (Decker et al. 2014) and an aging workforce, entrepreneurship and innovation raise economic growth, provide jobs, and rebuild government coffers. As America works to rebuild from the devastating effects of the COVID-19 pandemic, these stimulants become ever more important. This chapter reviews potential reforms to the US immigration system that could enhance the contribution of immigrants to the nation's entrepreneurship and innovation.

Policy makers are well aware of high-profile immigrant examples like Tesla and SpaceX founder Elon Musk and Microsoft CEO Satya Nadella, whose images grace the covers of magazines and who are called to testify

Sari Pekkala Kerr is an economist and a senior research scientist at the Wellesley Centers for Women (WCW) at Wellesley College.

William R. Kerr is the D'Arbeloff Professor of Business Administration at Harvard Business School, a Bank of Finland Research Fellow, and a research associate of the National Bureau of Economic Research.

We thank Maggie Dalton and Gorick Ng for excellent research assistance. We thank the National Science Foundation, Smith Richardson Foundation, Harvard Business School, and the Ewing Marion Kauffman Foundation for financial support that made this research possible. The research in this chapter was conducted while the authors were Special Sworn Status researchers of the US Census Bureau. Any opinions and conclusions expressed herein are those of the authors and do not necessarily represent the views of the US Census Bureau. This research was performed at a Federal Statistical Research Data Center under FSRDC Project Number 1731. All results have been reviewed to ensure that no confidential information is disclosed. For acknowledgments, sources of research support, and disclosure of the authors' material financial relationships, if any, please see https://www.nber.org/books-and-chapters /innovation-and-public-policy/immigration-policy-levers-us-innovation-and-startups. 
before Congress. They may be less aware, however, of the exceptional depth that lies below these prominent examples. Immigrants account for about a quarter of US start-ups and patents each year, a share that has been increasing for decades. Section 3.2 reviews some recent economic research about immigrant entrepreneurship and innovation and its surprisingly deep influence on the US economy.

Section 3.3 then discusses adjustments to US immigration policy that could boost innovation. We mostly focus on feasible reforms that would operate within the current immigration structure by adjusting the allocation of visas granted for employment-based purposes. The most prominent reform would replace the lottery used for the oversubscribed H-1B visa system with an allocation mechanism that prioritizes specified uses. We also provide a short discussion of comprehensive immigration reform, which could increase the relative share of immigration for employment-based purposes compared to family-reunification purposes.

Section 3.4 considers policies connected to immigrant entrepreneurs. While the United States has visas that cover individuals capable of making substantial business investments, its immigration structure is less accommodating than those of other countries for the admission of business founders lacking existing financial capital (e.g., an immigrant college student on an F-1 student visa who wants to start a company after graduation). We review the approaches of several countries to start-up visas, common traits of recent US legislative proposals, and estimates of the potential economic impact.

Throughout this review, we strictly follow the National Bureau of Economic Research's guideline that papers not advocate a particular policy approach. Our goal is to collect and present economic research on how policy makers can influence US entrepreneurship and innovation outcomes through the immigration process. We thus skip discussion of policies that indirectly influence immigrant entrepreneurship and innovation. An example is the work of Akcigit, Baslandze, and Stantcheva (2016), which shows that top inventors are very sensitive to taxation rates when deciding where to conduct their research. Many of these policies are covered elsewhere in this volume and in Bloom, Van Reenen, and Williams (2019), and these levers often operate in part by making the United States more attractive to skilled immigrants. Similarly, we do not quantify what an overall expansion of US immigration rates would do for entrepreneurship and innovation, as most of the impact would simply come from the larger economy (Clemens 2011).

Our focus is narrower and arguably more useful to policy makers in today's immigration discussions. In America and abroad, recent growth in populism and nationalism has pushed back at many forms of global integration, including skilled- and employment-based migration. Questions about the appropriateness of global linkages will further intensify following the COVID-19 crisis. Yet the combination of a knowledge-intensive economy 
and a rapidly aging populations in most advanced economies suggests that competition for the world's mobile entrepreneurs and innovators will increase in the decades ahead. Understanding what policy margins could be adjusted is an important foundation for thinking through future national strategies for immigration and the best mechanisms to implement them.

\subsection{Immigrants as Founders and Innovators}

While the literature on immigrant entrepreneurship and innovation is not very extensive, it is nonetheless too large to be fully reviewed here. We instead outline some key research findings that provide important background for the immigration visa discussions in the next two sections. ${ }^{1}$

1. Immigrants account for about a quarter of US entrepreneurship and innovation. A significant body of work over the past two decades has quantified these contributions. ${ }^{2}$ Measuring this is harder than it first appears, which results in a range of techniques and estimates. Nevertheless, research consistently finds that immigrants account for about 25 percent of new firms and patents. As a corollary, the propensity of immigrants toward entrepreneurship and innovation is higher than it is for US natives. ${ }^{3}$ Immigrants account for about 14 percent of the US workforce and 17-18 percent of US college graduates, according to the 2016 American Community Survey. Looking specifically at science and engineering, immigrants account for 29 percent of the United States' college-educated workforce and 52 percent of its doctorates.

2. Most of the heightened impact of immigrants on US entrepreneurship and innovation comes from a greater propensity of immigrants to possess the educational backgrounds for the work. Hunt $(2011,2015)$ shows that immigrants' propensities toward entrepreneurship and innovation can be mostly explained through their greater educational attainment and their greater focus on the STEM fields (science, technology, engineering, and mathematics). While immigrants are more represented at the upper tail of scientific achievement ${ }^{4}$ - accounting, for example, for a third of US-based recipients of Nobel Prizes - their most significant impact on the economy comes through the large quantity of immigrant workers trained for pursuing STEM work.

1. Kerr (2019a) provides a book-length review. Summary articles include Fairlie and Lofstrom (2014), Kerr (2017), and Kerr et al. (2016, 2017).

2. For example, Anderson and Platzer (2006); Azoulay et al. (2020); Bernstein et al. (2019); Brown et al. (2019); Kerr and Kerr (2017, 2020); Kerr and Lincoln (2010); Saxenian (1999, 2002); and Wadhwa et al. (2007).

3. The diverse literature spans Borjas (1986); Clark and Drinkwater (2000, 2006); Fairlie (2012); Fairlie and Lofstrom (2014); Fairlie, Zissimopoulos, and Krashinsky (2010); Hunt (2011, 2015); Lofstrom (2002); and Schuetze and Antecol (2007).

4. See, for example, Hart and Acs (2011); Kerr (2019a, 2019b); Peri (2007); Stephan and Levin (2001); and Wadhwa et al. (2007). 


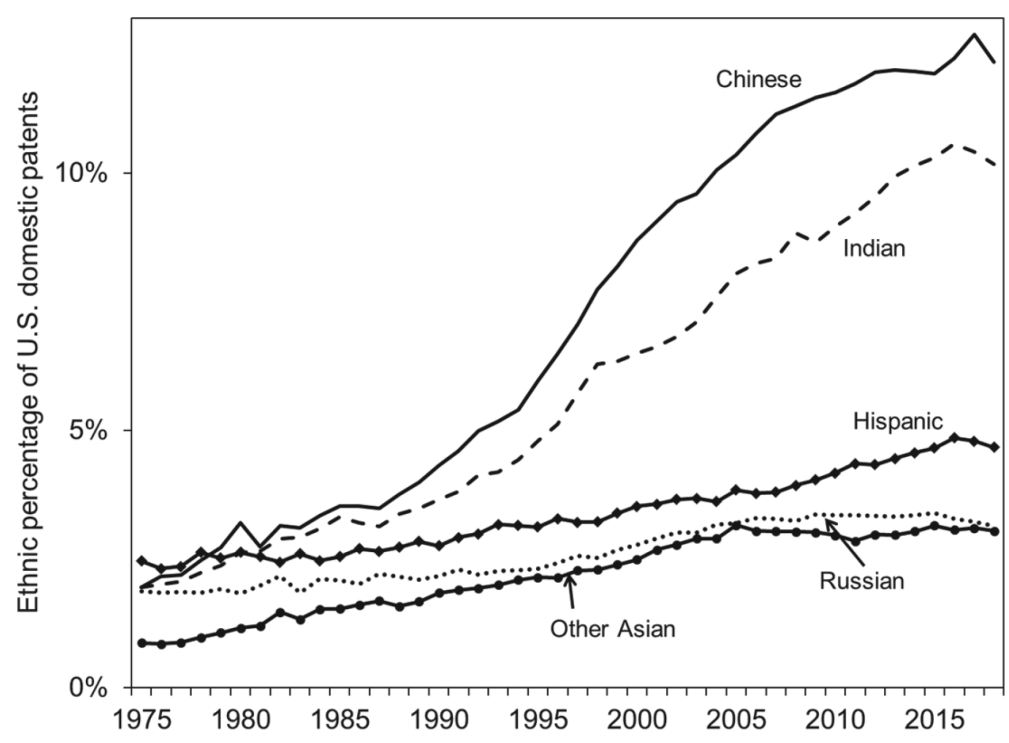

Fig. 3.1 Ethnic share of patents filed by inventors living in United States

Source: Data from US Patent and Trademark Office. Series uses ethnic naming conventions applied to inventors based in the United States.

3. Chinese and Indian immigration have been particularly strong drivers for growth in immigrant entrepreneurship and innovation. To provide an extended time horizon, figure 3.1 uses the ethnic-name-matching algorithms of Kerr (2008) to quantify the significant growth in US patents granted to individuals of Chinese and Indian ethnicity working in America. Chinese and Indian ethnic inventors accounted for less than 3 percent of US patents in 1975, but more than 22 percent in 2018. As we discuss later, this concentration is leading to long delays in obtaining US permanent residency for immigrants from China and India due to the US allocation procedures that cap the annual number of green cards that can go to petitioners who were born in any given country.

4. Immigrant entrepreneurship and innovation are quite clustered spatially and show no evidence of crowding out native activity in local areas. More than half of entrepreneurs in the San Francisco Bay Area are foreign-born, and many other leading technology clusters show high immigrant shares (Kerr and Kerr 2020). Empirical studies using geographic variation almost always find positive or no impact from high-skilled immigration on native employment and output in innovative activities in the same city. ${ }^{5}$ This clustering

5. For example, Buchardi et al. (2019); Ghimire (2018); Hunt and Gauthier-Loiselle (2010); Kerr (2010); Kerr and Lincoln (2010); and Peri, Shih, and Sparber (2015). Lewis and Peri (2015) provide a theoretical framework and review of literature on the effects of immigration on local areas. Analyses of industries or technology areas have shown more mixed outcomes (e.g., Borjas 
has substantially shifted the economic geography of innovation in America, and the lack of a crowding-out effect allows the spatial concentration of innovation to persist and grow. We note later the potential role of regional visas to counteract some of this concentration.

5. Immigrant contributions are similarly concentrated within firms, with mixed evidence for whether native employment grows or declines. Firms such as Microsoft and Google employ skilled immigrants to a greater degree than Procter and Gamble and Boeing. These differences can be explained in part by their physical locations and industries. Studies on whether the hiring of skilled immigrants boosts the overall employment of firms show mixed results (e.g., Dimmock, Huang, and Weisbenner 2019; Doran, Gelber, and Isen 2015; Kerr, Kerr, and Lincoln 2015b; Mayda et al. 2018), an ambiguity connected to the many ways the US visa system can be used, as described in the next section. There is evidence that high-skilled immigration is a lever used by employers to keep tech workforces younger (e.g., Kerr, Kerr, and Lincoln 2015a, 2015b; Matloff 2003). ${ }^{6}$

6. Skilled immigrants receive wages at a rate comparable to similarly skilled natives. Studies on whether immigrants receive higher or lower wages than natives yield mixed results. Legal factors, like the prevailing wage requirement for an H-1B worker, limit the extent to which pay differences could exist. Moreover, even to the degree that skilled immigrants are slightly underpaid relative to natives of similar age and background, the economics of the firm suggest a rather limited scope for this differential to influence hiring decisions. The larger wage gaps instead appear between younger skilled immigrants and older native workers, connecting to the observation above that high-skilled immigration can be a mechanism for firms to keep workforces younger.

7. A substantial portion of skilled immigration to America begins with migration for schooling. Immigrants who contribute to US entrepreneurship and innovation migrate at many life stages: Sergey Brin of Google migrated as a child, while Elon Musk first moved to the United States for college. The reforms below focus on entrepreneurial and employment opportunities after schooling, but Kato and Sparber (2013) demonstrate a strong link between the opportunity to remain in the United States for work and the attractiveness of US colleges to migrants. Likewise, policies that govern school-towork transitions play an important role.

and Doran 2012; Bound, Khanna, and Morales 2017; Doran and Yoon 2019; Moser and San 2020; Moser, Voena, and Waldinger 2014). The clustering of entrepreneurs from a country in a narrow occupation is widespread and studied by Chung and Kalnins (2006), Fairlie, Zissimopoulos, and Krashinsky (2010), Kerr and Mandorff (2015), and Patel and Vella (2013). See also the self-employment studies of Akee, Jaeger, and Tatsiramos (2013), Fairlie and Meyer (2003), and Lofstrom (2002).

6. The transition period for native workers who are displaced appears longer in STEMconnected work than elsewhere (Kerr and Kerr 2013). Glennon (2019) considers how access to skilled immigrants influences the overseas operations of US firms. 


\subsection{Visas for Innovators}

The research findings described in section 3.2 provide a foundation for exploring how the US immigration process can be adjusted to increase levels of entrepreneurship and innovation. This section commences by discussing the role of immigrants in invention and innovation. The bulk of these contributions come through the actions of paid employees in US businesses, and thus we focus on the frameworks that connect to the quantity and composition of these workers. Section 3.4 considers the special case of immigrant entrepreneurs who are not well aligned for employment-based visas. ${ }^{7}$

\subsubsection{A Brief Summary of the US Immigration System}

The US immigration system is vast and exceptionally complex, and we highlight here just a few important background pieces. ${ }^{8}$ Most of the poli-

7. This chapter describes the policy environment in April 2020, when the chapter was prepared. From April 2020 until the chapter went to press in November 2020, there were a number of temporary and potentially long-term changes to US immigration policy and enforcement. Some of these actions were framed as a response to health and employment concerns related to the COVID-19 pandemic, and other countries restricted migration to some degree during the pandemic's spread. In June 2020, the Trump administration suspended new H-1B and L-1 visa issuances to most individuals outside the country through the end of the year. These restrictions followed on other restrictions emanating in April 2020, and a federal judge later issued a preliminary injunction against them. In early October, the Trump administration introduced two "interim final" regulations that would forego normal notice and commentary periods. The first, through the Department of Labor (DOL), immediately changed the calculation of the required wage for H-1B employees, effectively increasing minimum salaries. The second, through the Department of Homeland Security (DHS), required that the degrees of H-1B candidates be directly related to the proposed occupation (e.g., a candidate with a degree in mechanical engineering cannot fill a job designated for computer programming), and limited visa duration to one year for H-1B holders who work at customer or third-party sites. The DHS regulation was set to take effect in December 2020, and both DOL and DHS regulations are being legally challenged. The Trump administration also proposed a new rule to eliminate the H-1B lottery in favor of a wage-ranking system. With the November 2020 election of Joe Biden to the presidency, the future of these changes is uncertain. See White House, "Proclamation Suspending Entry of Aliens Who Present a Risk to the U.S. Labor Market Following the Coronavirus Outbreak," Executive Order, July 22, 2020, https://trumpwhitehouse.archives.gov/presidential -actions/proclamation-suspending-entry-aliens-present-risk-u-s-labor-market-following -coronavirus-outbreak/; Employment and Training Administration, "Strengthening Wage Protections for the Temporary and Permanent Employment of Certain Aliens in the United States," Federal Register, October 8, 2020, https://www.federalregister.gov/documents/2020 /10/08/2020-22132/strengthening-wage-protections-for-the-temporary-and-permanent -employment-of-certain-aliens-in-the; Department of Homeland Security, "Strengthening the H-1B Nonimmigrant Visa Classification Program," Federal Register, October 8, 2020, https://www.federalregister.gov/documents/2020/10/08/2020-22347/strengthening-the-h-1b -nonimmigrant-visa-classification-program; Department of Homeland Security, "Modification of Registration Requirement for Petitioners Seeking to File Cap-Subject H-1B Petitions," October 28, 2020, https://www.dhs.gov/sites/default/files/publications/20_1028_uscis_h-1b -registration-selection-by-wage-levels-nprm-508.pdf.

8. For a primer, see Julia Gelatt, "Explainer: How the U.S. Legal Immigration System Works," Migration Policy Institute, April 2019, https://www.migrationpolicy.org/content lexplainer-how-us-legal-immigration-system-works. 
cies discussed below fall under the US Citizenship and Immigration Services (USCIS) within the Department of Homeland Security.

Other than citizenship, immigration to America culminates in obtaining permanent residency, also known as the "green card." Approximately 1 million green cards are granted every year, with family-based immigration being the largest category. There is no annual limit on green cards to reunite immediate family members (e.g., spouses, parents, and children) of American citizens, and up to 480,000 additional visas are provided annually for extended family. Green cards granted for employment-based purposes are subject to an annual cap of 140,000 individuals, including family members accompanying the worker. Smaller numbers of visas are issued for other purposes, such as refugee/humanitarian concerns.

In parallel, temporary visas authorize individuals to visit, study, and work in the United States. These visas are termed "nonimmigrant" as the individual does not have permanent rights to stay in the country. Temporary visas are often a predecessor to permanent residency, as more than 80 percent of employment-based green cards are issued to individuals already living and working in the United States. On the other hand, many skilled migrants work in the United States for a period of time but have no intention to stay permanently. Consequently, the levers by which policy makers might impact entrepreneurship and innovation extend beyond permanent residency admissions to cover temporary visas and, as we will return to below, how these two structures interface with each other. This section continues by describing temporary visas for employment-related purposes (versus to study or to visit).

A distinctive feature of the US temporary visa system is that it is "employer driven," meaning that a company like Microsoft or General Motors selects the worker it wants to employ and applies for a visa on behalf of the worker. This individual could be living/working abroad or be a student at a US school on a nonemployment visa. This employer-driven approach contrasts conceptually with a points-based system that scores and selects potential immigrants based on their attributes (e.g., degree, age, language skills, income). Kerr (2019a) reviews the trade-offs between the two approaches and the de facto hybrid nature of many nations. The United States has some elements of a points-like structure in that priority temporary visa categories (and permanent residency admissions) exist for persons of "extraordinary ability," but the bulk of skilled immigrant workers are admitted through temporary visas that rely on employers to select migrants.

The largest of these temporary employment-based categories is the $\mathrm{H}-1 \mathrm{~B}$ visa for skilled foreigners working in "specialty occupations" (i.e., those requiring theoretical and practical application of specialized knowledge like engineering or accounting). Virtually all $\mathrm{H}-1 \mathrm{~B}$ holders have a college education or higher, and the substantial majority of visas are used for computerand STEM-related occupations. In 2017, immigrants from India accounted 


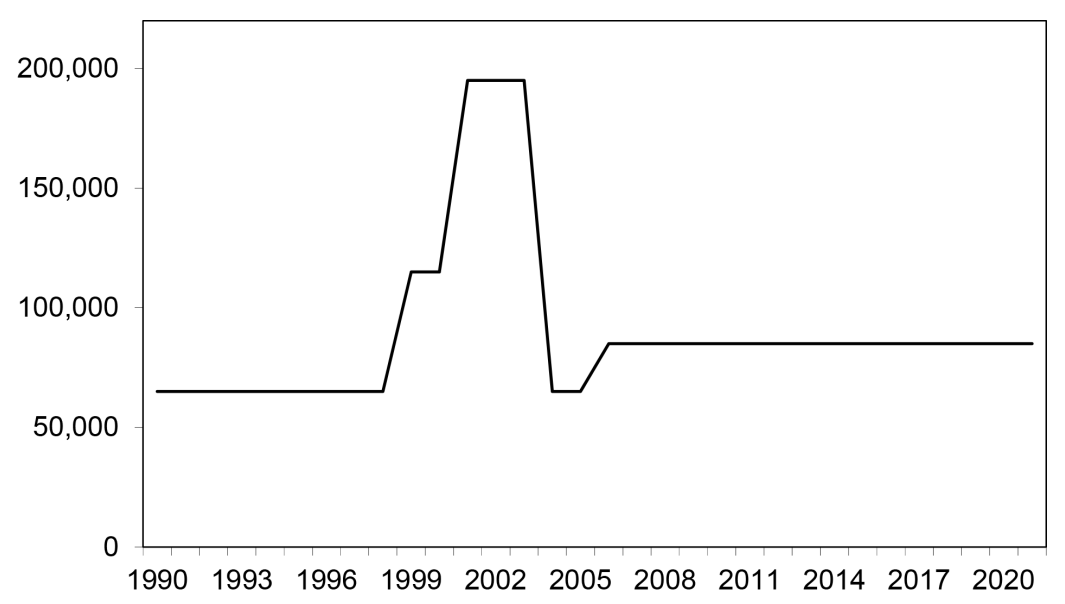

Fig. 3.2 Evolution of $\mathbf{H}-1 \mathrm{~B}$ cap by fiscal year

Source: Data from US Citizenship and Immigration Services.

for 72 percent of H-1B visas, and immigrants from China were awarded another 13 percent. These shares have steadily risen and demonstrate the flexibility of the system to be used in ways that employers deem fit, with computer- and STEM-related occupations being attractive opportunities for firms.

H-1B holders are tied to their sponsoring firm, although visa portability is feasible with approval from the government (e.g., Depew, Norlander, and Sorensen 2017). Firms can petition for permanent residency on behalf of the worker. This "dual-intent" feature - where one can be a temporary migrant but also apply for permanent residency - is attractive to many immigrants. The H-1B visa is for three years and can be renewed once. If permanent residency is not obtained, the $\mathrm{H}-1 \mathrm{~B}$ worker must leave the United States at the end of the second visa period for one year before applying again.

Firms must pay the visa holder the higher of (1) the prevailing wage in the firm for the position or (2) the prevailing wage for the occupation in the area of employment. Congress designed these restrictions to prevent $\mathrm{H}-1 \mathrm{~B}$ employers from abusing their relationships with foreign workers and to protect the wages and employment of domestic workers. In 2016, the average salary for H-1B visa holders was $\$ 80,000$, but there was a broad range, from midskilled employees of outsourcing firms earning $\$ 60,000$ to higher-skilled workers earning greater than $\$ 150,000$ (Kerr 2019b; Ruiz and Krogstad 2018). ${ }^{9}$

Figure 3.2 shows the annual cap on the number of new H-1B visas that

9. The minimal wage effects on R\&D workers from expanding skilled immigration for innovation is different from wages being bid up from R\&D stimulus described by Goolsbee (1998). 
can be issued to for-profit firms. The original 65,000 cap was not binding in the early 1990s, but became so by the middle of the decade. Legislation in 1998 and 2000 sharply increased the cap over the next five years, to 195,000 visas. These short-term increases expired during the high-tech downturn, when visa demand fell short of the cap. The cap returned to the 65,000 level in 2004 and became binding again, despite being subsequently raised by 20,000 through an "advanced degree" exemption. The overall cap of 85,000 remains in place as of 2020.

Another widely used but lesser known employer-based visa is the L-1. Available for the temporary migration of foreign employees within a multinational firm, there were about 78,000 L-1 visas (including renewals) issued in 2017. Only employees who have been employed by the firm for at least one of the previous three years are eligible, and the visa has a maximum stay of seven years. Similar to the H-1B, the L-1 is a dual-intent visa, whereby it provides an opportunity to apply for a green card. Yeaple (2018) provides additional discussion of the L-1 visa.

\subsubsection{Potential Reforms within the Existing System}

Lawmakers have proposed several reforms that could boost entrepreneurship and innovation by, more or less, adjusting the existing system (i.e., not requiring the comprehensive immigration reform described at the end of this section). We discuss these reforms, working backward from the green card decision.

\subsubsection{Remove Country Caps on Employment-Based Permanent Residency}

The United States grants 140,000 green cards for employment-based (EB) purposes each year, a figure that includes the focal worker and his or her accompanying family members. This is not the only pathway through which an immigrant inventor or entrepreneur can obtain permanent residency as, for example, the individual may marry an American citizen and apply for permanent residency through family-based allocations. Others enter the diversity lottery that offers 50,000 green cards randomly to applicants from countries with low rates of admission to America. Nevertheless, the EB allocation is the most central and broadly accessible channel for employmentconnected immigration.

In addition to these caps on the type of green card to be awarded (which we discuss in greater detail below in the context of comprehensive immigration reform), the US system has an important country-level cap. A provision within the Immigration Act of 1990, which remained in effect as of 2020 , stipulated that "the total number of immigrant visas made available to natives of any single foreign state or dependent area" not exceed 7 percent. This provision was partly designed to encourage diversity in source countries of migrants. 
A consequence, however, has been the development of long waiting lists for employment-based migrants from several large nations until they can obtain a green card (e.g., Kahn and MacGarvie 2018). EB immigrants from China and India face particularly long waiting times given the huge demand: recall that 85 percent of H-1B visas go to immigrants from these two countries, and figure 3.1 showed their prominent role in US innovation growth. Wait-time projections for some categories of Indian migration can stretch into the decades (priorities and wait times depend on the skill level of the EB category). Though the H-1B temporary visa can be extended beyond the typical six years (initial plus renewal) while the immigrant is waiting for a green card, the long wait times impair worker mobility across employers and their capacity to launch new ventures.

Over the last decade, attempts have been made in both the House and the Senate to amend this policy. Proposals have suggested increasing the country cap from 7 percent to 15 percent or 25 percent, and avoiding any residual, unused visas. A prominent recent example is the Fairness for High-Skilled Immigrants Act of 2020, proposed in both the House and the Senate, which sought to "eliminate the per-country numerical limitation for employmentbased immigrants." Different forms of the proposal passed the House and Senate but were not reconciled before the 116 th Congress ended its session. ${ }^{10}$

This adjustment would likely increase the attractiveness of the United States to foreign entrepreneurs and innovators. For immigrants doing innovative work in large organizations, the prospect of long waiting times can deter migration due to the uncertainty and possibly slower wage growth while on temporary status. Hunt (2017) finds that mobility is reduced by about 20 percent when waiting for green card processing. The weakened mobility of workers may also reduce the match quality between a firm and a worker, leading to lower productivity. Prospective entrepreneurs can also be discouraged if they need the permanent residency transition to start their business, due either to legal factors (visa requirements) or to the necessary confidence that the United States will be their long-term home.

\subsubsection{Increase the Number of H-1B Visas}

The most frequently proposed and debated reform to temporary migration is to raise the annual cap on the H-1B program for for-profit firms. As of

10. This section is sourced from the following (accessed December 2019): 8 U.S. Code $\S 1152$, Numerical Limitations on Individual Foreign States, https://uscode.house.gov/view.xhtml ?req=(title:8\%20section:1152\%20edition:prelim; Startup Act, S. 1877, 115th Congress, 2017, https://www.congress.gov/bill/115th-congress/senate-bill/1877/text\#toc-H6343391472A44B F0884BAD0CFF83B119; Fairness for High-Skilled Immigrants Act of 2019, S. 386, 116th Congress, 2019, https://www.congress.gov/bill/116th-congress/senate-bill/386/text; Fairness for High-Skilled Immigrants Act of 2020, H.R. 1044, 116th Congress, 2019, https://www.congress .gov/bill/116th-congress/house-bill/1044/text; Fairness for High-Skilled Immigrants Act of 2019, S. 386, 116th Congress, 2019, https://www.congress.gov/bill/116th-congress/senate-bill /386/actions; Fairness for High-Skilled Immigrants Act of 2019: Roll Vote No. 437, Congressional Record, July 10, 2019, http://clerk.house.gov/evs/2019/roll437.xml. 
early 2020 , the H-1B visa cap was 65,000 with an additional 20,000 visas for individuals with advanced degrees from US schools. Many proposals fall in the range of 115,000 to 195,000 visas. Some prominent business leaders like Eric Schmidt, Google's former CEO, go further to advocate for an unlimited number of visas. ${ }^{11}$ Policy makers might also consider indexing future caps to economic conditions and related factors so that Congress does not need to spend multiple years debating one-off adjustments to a nominal figure.

It is likely that such a cap increase would spur US innovation to some degree. Empirical and quantitative studies of the prior cap adjustments when binding ${ }^{12}$ suggest this conclusion, although a study of marginal visa awards in the non-cap-binding years of 2006 and 2007 does not (Doran, Gelber, and Isen 2015).

The most frequent objection raised to a potential innovation boost is that most $\mathrm{H}-1 \mathrm{~B}$ visa holders are not conducting innovative work (being employed in computer- and STEM-related positions more broadly). Although this is true, it remains the case that innovation would likely grow if the overall program expanded. By analogy, an expansion of the Department of Defense's budget would likely result in more tanks, even though tanks are only a small portion of the department's budget. What this objection surfaces, though, is that we do not know how the overall composition of the applicant pool would change under an expanded program. The composition could stay the same, deteriorate on average (e.g., if firms apply for more marginal visa uses), or increase (e.g., if the greater assurance of a visa led to higher-quality immigrants and to firms prioritizing more to locate in the United States).

While many advocates propose cap expansions without reference to other policies, the interaction of such an expansion with other aspects of the immigration pathway should be considered by policy makers. Most important, without potential adjustments to the 7 percent country cap regarding how EB green cards are allocated, the backlog of temporary visa holders from China and India waiting for green cards would grow substantially if only the $\mathrm{H}-1 \mathrm{~B}$ cap were increased.

\subsubsection{Adjust the H-1B Visa Allocation Mechanism}

Additional proposals consider how the United States could adjust the allocation of H-1B visas. Prior to fiscal year 2021, the visa application period opened on April 1 of each year. In most years, the government received more

11. Schmidt said in 2017, "The single stupidest policy in the entire American political system was the limit on H-1B." S. A. O'Brien, "Alphabet's Eric Schmidt Says H-1B Visa Cap Is 'Stupid,'” CNN, May 4, 2017, https://money.cnn.com/2017/05/04/technology/eric-schmidt -h1b-visa/. Hira (2010), by contrast, provides an example of a very skeptical view on the program. In a 2019 survey of Harvard Business School alumni (Porter et al. 2019), 70 percent of respondents favored an increase in the H-1B cap of 50 percent or more. In a parallel poll of the general public, 30 percent of Democrats and 20 percent of Republicans expressed interest in such an increase.

12. For example, see Bound, Khanna, and Morales (2017); Kerr, Kerr, and Lincoln (2015a, 2015b); Kerr and Lincoln (2010); Mayda et al. (2018); Peri, Shih, and Sparber (2015). 


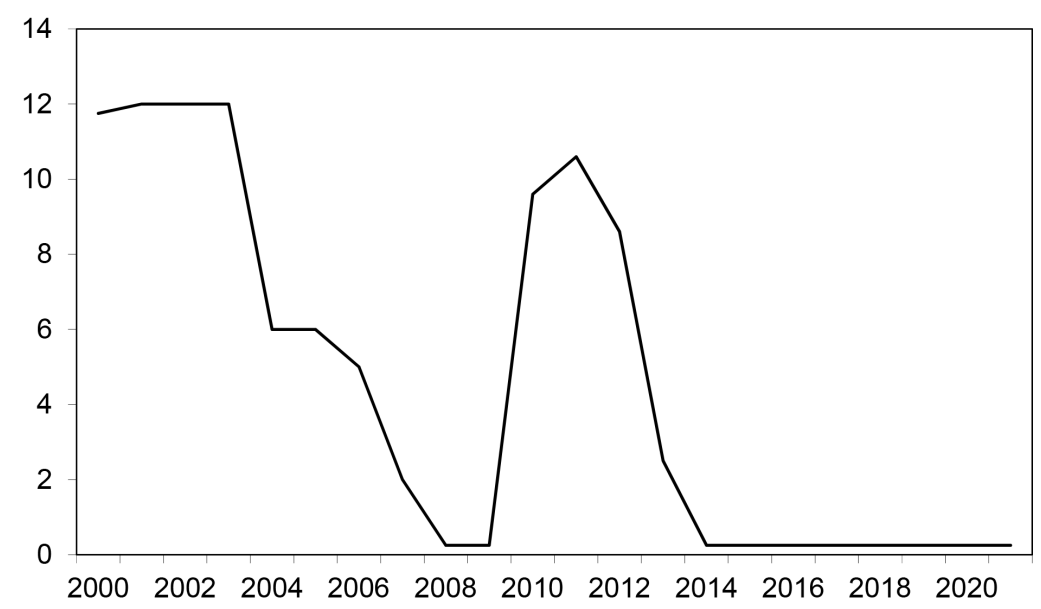

Fig. 3.3 Months until H-1B cap is reached from filing start date by fiscal year Source: Data from US Citizenship and Immigration Services.

Notes: Cap was not reached in fiscal years 2002-2003.

applications than the available cap within the first week. The policy of the government in these oversubscribed years was to keep accepting applications for a whole week and then conduct a lottery for the applications received. Should the cap not be reached in the first week, applications were processed on a first-come, first-served basis until the cap was reached later in the year (and on that final day, USCIS conducted a mini lottery for the applications received on the day when the cap was reached). Figure 3.3 shows how rapidly the cap fills in most years. USCIS received 201,011 applications by April 5, 2019, for the 2020 fiscal year. ${ }^{13}$ In March 2020, USCIS implemented a new two-step application process for fiscal year 2021, with a first registration from March 1, 2020, through March 20, 2020, followed by a lottery selection. Early data suggested that the government received approximately 275,000 registrations, again well in excess of the cap. At the time of writing this chapter, it was uncertain if the USCIS would further modify this new process for future years.

The lottery has important implications. A lottery randomizes applications and thus gives an equal chance to an applicant performing basic code testing for an outsourcing company as it does to one performing artificial intelligence research with a proposed salary tenfold higher. Indeed, the lottery system likely even tilts the application pool further toward more mundane uses: it is easier for a company to submit multiple applications for a routine

13. See Kumar, "H1B Visa Cap Reach Dates History FY 2000 to 2021 - Graph-USCIS Data," Redbus, February 3, 2021, https://redbus2us.com/h1b-visa-cap-reach-dates-history -graphs-uscis-data/. 
software developer role, knowing that the overall odds per applicant are in the range of 40 percent, than it is for a company to submit multiple applications for a scarce skill set like artificial intelligence research. (In a comparable way, it is likely that the lottery favors large companies submitting many H-1B applications over smaller companies who have more discrete needs.)

One recent change shifted in subtle ways the skill composition. USCIS has historically conducted the 20,000 visa lottery for candidates with a master's education from US schools before the 65,000 regular lottery. As candidates with master's degrees from US schools could enter both lotteries, this lottery order meant that fewer candidates with master's educations entered the regular lottery because they had already been selected. USCIS reversed the lottery order starting with the H-1B applications received in April 2020 for fiscal year 2021. By reversing the order, more of the dual lottery applicants will be chosen via the 65,000 lottery (and thus will drop out of the 20,000 exempt lottery). Estimates suggest that this change will increase by 4,000 to 5,000 individuals the number of $\mathrm{H}-1 \mathrm{~B}$ visas awarded to holders of master's degrees. There have been some legal challenges to the proposed change, and others have argued against the switch in lottery order by noting, for example, that it would deprioritize applicants with doctorate degrees from non-US schools. ${ }^{14}$ Pathak, Rees-Jones, and Sönmez (2020) provide an extensive analysis of this rule change and its optimality under the existing $\mathrm{H}-1 \mathrm{~B}$ structure.

A move away from the lottery system altogether would likely increase the innovative output of the H-1B program. One mechanism frequently debated is to rank applicants by their proposed wage (which is included as part of an H-1B application). This technique would use the worker's wage as an imperfect proxy for the value of the potential immigrant to the US economy. A potential advantage of this approach is that the procedure is easy to understand and convey to the public. To the degree that wages and skills are correlated, such a prioritization would also raise the skill content of the H-1B system significantly. Sparber (2018) calculated that this change would generate a $\$ 27$ billion surplus over six years, with gains even higher should better talent become more incentivized to apply.

14. From an applicant's perspective, one site estimated that the new lottery order would increase the likelihood that the holder of a US master's degree would obtain a visa from 51 percent to 55 percent, while reducing others from 38 percent to 34 percent. See AM22Tech Team, "What Is H1B Lottery System, Chances of Selection in Apr 2021?," AM22Tech, December 25, 2020, https://www.am22tech.com/h1b-lottery-system-changes/. Significant recent debate has also centered on the H-4 authorization that allows dependent spouses of $\mathrm{H}-1 \mathrm{~B}$ workers with approved green card petitions to work. As of April 2020, the USCIS was considering an end to this authorization. Some H-1B holders have expressed concern that they will not be able to afford to live in the United States without a second income. It is not clear that this rule change would impact the innovation and entrepreneurship outcomes that are the focus of this chapter. Finally, several additional processing actions taken by the Trump administration appear to have aimed at reducing the number of H-1B visas awarded to IT service providers. In March 2020, a court invalidated several of these actions, and the future legal path is uncertain (Anderson, 2020a, 2020b). 
There are some potential disadvantages that would need to be addressed. First, wage ranking would naturally favor some higher-priced cities and industries (e.g., New York City for finance, San Francisco for tech) over others, established companies over smaller ones, and established workers over younger ones and new college graduates. Lawmakers would need to consider what additional adjustments should complement and support wage ranking, such as regional and/or occupational caps, adjustments of schoolto-work transitions, etc. ${ }^{15}$ Second, the status implications to the temporary worker of subsequent cuts in salary compared to the initial offer use for wage ranking will need to be specified. Finally, wage ranking might also face legal challenges from groups that favor the current system, especially Indian outsourcing companies that argue the visas are compliant with the World Trade Organization's General Agreement on Trade in Services. ${ }^{16}$

Two other proposals are worth noting. One, which could complement wage ranking, is to establish a minimum salary level for an H-1B worker (e.g., \$100,000), possibly with buffer mechanisms that would save unused visas and add them to subsequent years when demand spikes again. These thresholds would ensure that visas are allocated to purposes other than just cost minimization in IT roles.

Another proposal is to auction visas to companies (e.g., Peri 2012). Auctions would likely bring many of the same skill increases and innovation gains as wage ranking. Auctions would differ in that more of the economic surplus that immigration generates would be captured by the government, which could then use the funds as it deems fit. A challenge is that auctions would likely raise the share of $\mathrm{H}-1 \mathrm{~B}$ visas going to companies that are already large and doing well, as they have the greatest financial capacity to bid for visas.

\subsubsection{Adjust School-to-Work Transitions}

This chapter focuses on policy reforms and how they might impact entrepreneurship and innovation in the for-profit sector. We do not provide here an in-depth treatment of potential reforms to immigration and the education system (Bound et al. 2020), which is an important early pathway for

15. Regional or occupation caps are also mentioned as potential H-1B reforms independent of wage ranking. Such reforms, depending upon how they were implemented, could result in a lower innovation stimulus if they shifted work out of tech clusters toward other purposes and regions. Related work on clusters includes Audretsch and Feldman (1996); Carlino and Kerr (2015); Fallick, Fleischman, and Rebitzer (2006); Feldman and Kogler (2010); Kerr and RobertNicoud (2020); Moretti (2019); Samila and Sorenson (2011); and Zucker, Darby, and Brewer (1998). Docquier et al. (2020), Nathan (2015), and Ottaviano and Peri (2006) are examples of work on local diversity and innovation outcomes.

16. There could also be management challenges inside companies. For example, many companies have salary bands for positions that might be stressed in a company willing to offer a higher salary in order to obtain a worker. 
many who later take temporary work visas or EB green cards. However, we note several important tensions within the school-to-work transition.

US higher education is relatively unconstrained in that schools do not face caps on the number of student visas they can issue (or H-1B worker visas, as discussed later). Over the last decade, the number of foreign students in US schools has swelled to more than 1 million. Many of these students come to the United States with the hope of later obtaining a job in America (Kato and Sparber 2013). Yet the rapidly growing student population exerts pressure on the fixed supply of $\mathrm{H}-1 \mathrm{~B}$ visas. As a consequence, many immigrant students take their first job via the Optional Practical Training (OPT) program, which lets graduates work with US companies to gain practical experience in jobs connected to their majors, lasting for up to one year in most fields and three years for STEM-degree holders.

There are an unlimited number of OPT visa extensions, with roughly 175,000 active in 2017. The OPT program accounted for about 30 percent of foreign-born students entering the US labor market during the 2000s, and today more skilled immigrants start work via OPT than through $\mathrm{H}-1 \mathrm{~B}$ visas or permanent residency admissions (Bound et al. 2015). Many immigrants then experience the stress of repeatedly trying the H-1B lottery, with the hopes of being selected before their OPT runs out. If their OPT expires first, the student would need to leave the United States, obtain a different visa (e.g., O-1 or green card), or enter a new program (e.g., a master's degree). As the number of student and exchange visitor visas issued each year has grown to be an order of magnitude larger than the $\mathrm{H}-1 \mathrm{~B}$ visa cap (which also covers many applicants other than graduating students), the mismatch in program sizes has become acute.

An important policy question is how the United States might smooth school-to-work transitions. Many countries provide a guaranteed right to work for a period of time for students graduating their universities (e.g., three to five years regardless of degree); even from a narrow perspective, recent graduates and younger workers tend to be fiscal contributors by paying more in taxes than receiving in benefits. Policy makers may want to consider these adjustments on their own, but they would also become important under certain reforms, contemplated above, to increase the skill content of the $\mathrm{H}-1 \mathrm{~B}$ program. For example, with wage ranking or high $\mathrm{H}-1 \mathrm{~B}$ minimum wages, a fresh college graduate would be disadvantaged compared to an established worker. A hybrid model would provide workers a greater defined time before they need to compete for an H-1B slot.

Another common proposal is to "staple" a green card to any advanced STEM degree granted by a qualified US school to an immigrant. The staple proposal is a conceptually simple response to the challenges of school-towork transition, and it would likely boost entrepreneurship and innovation outcomes to some degree. A challenge to the idea is the scope of unintended 
consequences by attaching automatic rights to degrees. For example, comparable policies in other countries have encountered "diploma mills" that offer qualifying degrees under conditions that legislators had not anticipated. ${ }^{17}$ Even traditional US schools have already shown an increasing reliance on foreign students to help support themselves financially (e.g., Bird and Turner 2014; Bound et al. 2020).

\subsubsection{Potential Reforms to Broader Immigration Structure}

Closing this section, we note briefly the larger context of US immigration reform. The proposals described above could all likely boost the entrepreneurial and innovation output of US immigration without any change to the broad structure that favors family reunification. In 2016, approximately 12 percent of US green cards went for employment-based purposes, 68 percent for family reunification, and 20 percent for other purposes (e.g., diversity, humanitarian). This allocation is quite different from those of other countries with high levels of immigration, such as Canada, where a majority of slots are for employment-based purposes.

Comprehensive immigration reform could seek to change the overall level of immigration into America (i.e., increasing or decreasing the approximately 1 million green cards issued each year) or the relative allocation of types of green cards. Proposals often connect such a move to the adoption of a point-based system, including programs seeking to reduce immigration (e.g., the 2017 proposed Reforming American Immigration for Strong Employment [RAISE] Act ${ }^{18}$ ) and those seeking to expand it (e.g., proposals from the New American Economy). It is likely that an increase in levels or a composition shift toward employment-based migrants would boost entrepreneurial and innovation outcomes. For example, Hunt (2011) shows that immigrants entering through student and work visas are more likely to conduct entrepreneurial and innovative activities than those entering via other visa types. That said, this would constitute only one element of the substantial mix of political, social, cultural, and economic factors that matter for comprehensive reform.

\subsection{Visas for Entrepreneurs}

While countries have for decades adopted policies to attract and admit highly skilled immigrants, there is a recent and increasing interest in attract-

17. See "UK Rolls Out New Service to Help Fight Diploma Mills and Degree Fraud," ICEF Monitor, June 15, 2015, http://monitor.icef.com/2015/06/uk-rolls-out-new-service-to-help -fight-diploma-mills-and-degree-fraud/.

18. See Julia Gelatt, "The RAISE Act: Dramatic Change to Family Immigration, Less So for the Employment-Based System," Migration Policy Institute, August 2017, https://www.migration policy.org/news/raise-act-dramatic-change-family-immigration-less-so-employment-based -system. 
ing immigrant entrepreneurs. This is especially true around high-tech and high-growth start-ups. ${ }^{19}$ As immigrants display higher rates of entrepreneurship in the United States and many other countries, policy makers often consider immigration as a way to increase the supply of would-be entrepreneurs. This has resulted in a flurry of new entrepreneur visas: for example, Australia created a visa for immigrants with entrepreneurial skills in 2012, the United Kingdom introduced a new entrepreneur visa in 2008, and Canada created a similar program in 2013.

This section considers the special case of a start-up visa for America. We first review some of the established pathways for immigrant entrepreneurs under the US system and the challenges encountered. We then examine key dimensions of start-up visas seen in other countries. This segues to a review of US legislative proposals for a start-up visa act over the last decade, which have all thus far failed to make it to law, and some of the reforms that have happened.

\subsubsection{Traits of Immigrant-Founded Companies}

One newly available data source to characterize the contributions of immigrant entrepreneurs is the 2014 American Survey of Entrepreneurship (ASE). The 2014 ASE asked firms about their innovation activity and $\mathrm{R} \& \mathrm{D}$ efforts, in addition to posing standard questions regarding firm and owner characteristics. The ASE identifies the birthplaces of firm owners, allowing us to identify companies as native owners only, immigrant owners only, or mixed ownership. We focus our analysis on new firms founded in the past five years to align with entrepreneurship activity (versus transfer of businesses across owners) and in which one of the current owners was an original business founder.

Table 3.1 presents some simple tabulations. The full and weighted sample accounts for approximately 557,000 firms, with counts rounded per Census Bureau disclosure requirements. Of these ventures, 21.3 percent are entirely immigrant owned and 4.5 percent are immigrant owned in part. The table next provides for each column the share of ventures reporting the indicated activity. Firms with immigrant owners engage modestly more in R\&D and innovation than firms with only native owners. Mixed-founding teams show the greatest engagement in $R \& D$ and innovation, although this is partly because a mixed ownership team tends to be larger than a native- or immigrant-only ownership team (by definition, there must be at least two owners on a mixed team). Firms with immigrant owners are also more likely to be seeking expansion capital.

The last two rows use data on start-up financing to isolate 6,700 ventures

19. Anderson and Platzer (2006), Bengtsson and Hsu (2014), Fairlie (2012, 2013), Gompers, Mukharlyamov, and Xuan (2016), and Hegde and Tumlinson (2014) also consider immigrant roles among VC-backed companies and investors. Glaeser, Kerr, and Kerr (2015) and Haltiwanger, Jarmin, and Miranda (2013) describe employment growth and new firm formation. 


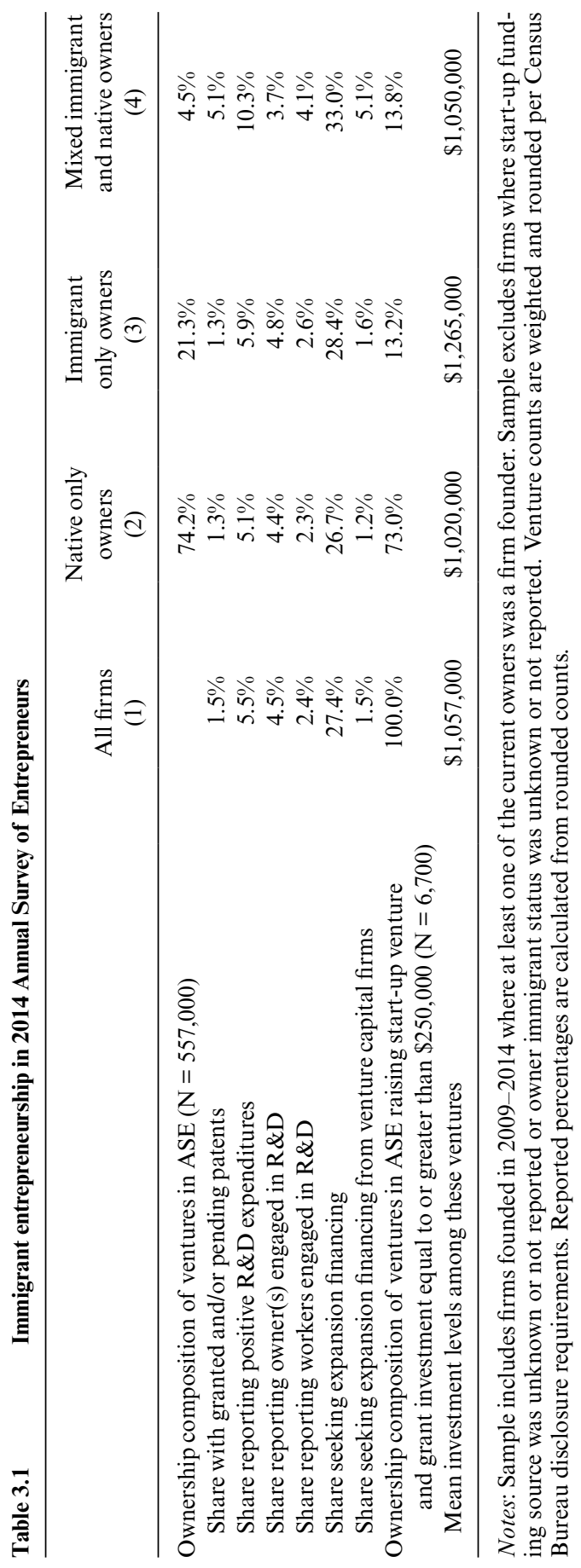


raising $\$ 250,000$ or more in private venture investment or public grants. Many start-up visa proposals suggest providing visas to immigrant founders who can raise this amount of start-up capital from either of these external financing sources. Such ventures in total account for a little over 1.2 percent of new ventures in the ASE sample. Firms with exclusively immigrant owners account for 13.2 percent of start-ups hitting these thresholds, and mixed teams account for another 13.8 percent. Ventures raising private venture investment or public grants at positive amounts less than $\$ 250,000$ account for about 2 percent of the ASE sample and have comparable immigrant ownership.

These tabulations confirm several important features of immigrant entrepreneurship, including the overall role of immigrant founders and their stronger proclivity toward innovative activities (e.g., Kahn, Mattina, and MacGarvie 2017). They also provide a sense of the relative shares of existing immigrant entrepreneurship that would have qualified for visas under some proposals. Existing experiences cannot forecast latent demand for new visas that are created, but they provide a sense of what policy makers may want to target.

\subsubsection{Pathways for Immigrant Entrepreneurs}

Many countries encourage the immigration of wealthy individuals willing to invest in a business that provides employment in the host country. The United States has an EB-5 permanent residency track for those willing and able to invest $\$ 1.8$ million into a US business. This minimum investment is an increase from the $\$ 1$ million required before November 2019. If the investment is made into so-called targeted employment areas that are rural or struggle with high unemployment rates, the minimum requirement is $\$ 900,000$ (up from $\$ 500,000$ ). Going forward, USCIS plans to adjust the index every five years according to inflation. The business must generate at least 10 full-time positions for American workers. The program provides a maximum of 10,000 visas per year, and this allotment is mostly reached each year. ${ }^{20}$

Aspiring immigrant entrepreneurs without this personal wealth who are not US permanent residents have two primary options for building a startup. The first option involves engaging in preliminary business planning while enrolled under F-1 status as a student, using the OPT period to launch and build the company, and then transitioning to an employment-based visa such as the O-1 or a self-petitioned green card via the EB-1A or EB-2 National Interest Waiver (NIW) category. The second option is to obtain

20. See US Department of State, "Report of the Visa Office 2018," https://travel.state.gov /content/travel/en/legal/visa-law0/visa-statistics/annual-reports/report-of-the-visa-office -2018.html; US Citizenship and Immigration Services, "About the EB-5 Visa Classification," updated March 25, 2021, https://www.uscis.gov/working-united-states/permanent-workers /about-eb-5-visa-classification. 
an employment-based visa like an $\mathrm{H}-1 \mathrm{~B}$, engage in preliminary business planning (without engaging in unauthorized employment or violating the terms of one's employment agreement), and then pursuing a green card from one's employer or from one of the aforementioned self-petition options. Blume-Kohout (2016) provides a complete description of these and other rarer routes.

These types of immigrant pathways are not well designed for entrepreneurs. The legal fees, uncertainty, and high adjudication standard involved in obtaining an O-1, EB-1A, or EB-2 NIW and employers' general reluctance to sponsor green cards often deter aspiring entrepreneurs. Roach and Skrentny (2019) measure in STEM fields the particular underrepresentation of immigrant $\mathrm{PhDs}$ working in tech start-ups compared to both their native peers and also to the expressed initial desire of the immigrants to be in a start-up. In a companion piece, Roach, Sauermann, and Skrentny (2020) identify the greater risk tolerance and alignment of personality traits of foreign PhD students to start-up activity, but the authors also show a gap between the early intentions of these students to be entrepreneurs and their employment outcomes after graduation. Roach, Sauermann, and Skrentny note that the limited capabilities of the US immigration system to support immigrant entrepreneurs likely plays an important role.

Consequently, a number of local attempts have sprung up to help immigrant entrepreneurs obtain the necessary employment authorization without waiting for permanent residency. Under the American Competitiveness in the Twenty-First Century Act of 2000, Congress made institutions of higher education and nonprofit organizations exempt from the $\mathrm{H}-1 \mathrm{~B}$ numerical cap. In 2014, the Massachusetts state legislature created an Entrepreneur in Residence (EiR) program whereby immigrant entrepreneurs with advanced STEM degrees could be sponsored on cap-exempt H-1B visas via working part-time at the University of Massachusetts Boston and part-time on their Massachusetts-headquartered start-ups. According to Global EiR Coalition, 13 such programs now exist at institutions such as the University of Colorado, Boulder, and the University of Missouri, St. Louis. ${ }^{21}$ Some venture capital firms have also devised packages that combine employmentconnected visa sponsorship (the entrepreneur works as an employee of the VC firm) with monetary investment. ${ }^{22}$

21. See Innovation Institute at the MassTech Collaborative, "What Is GEIR?," https://innovation .masstech.org/projects-and-initiatives/global-entrepreneur-residence-pilot-program; GlobalEIR, "Global EIR Locations," https://www.globaleir.org/global-eir-locations/.

22. See Jordan Crook, "Unshackled Is a New \$3.5M Early Stage Fund That Looks a Lot Like an Accelerator," TechCrunch, November 13, 2014, https://techcrunch.com/2014/11/13 /unshackled-is-a-new-3-5m-early-stage-fund-that-looks-a-lot-like-an-accelerator/. Several local policy initiatives have also sought to attract and welcome immigrant entrepreneurs more broadly (e.g., the Thrive competition in New York City and the Office of New Americans in Chicago). Some initiatives focus on specific issues that have been found to inhibit immigrant entrepreneurs from starting or growing their businesses (e.g., language barriers, difficulty navi- 


\subsubsection{International Examples}

Even though every country promotes the unique nature of its start-up visas, the visas tend to share many common features. ${ }^{23}$ In particular, startup visas tend to impose minimum requirements around one or more of these criteria: (1) the degree of establishment of the company, (2) the extent of ownership of the founding team, (3) the qualifications of the entrepreneur, (4) the economic impact of the venture, and (5) the financial self-sufficiency of the entrepreneur.

- Degree of establishment of the company: Countries typically require that ventures be less than a certain number of years old, with Singapore setting the bar at six months versus Ireland at six years. Countries also require that entrepreneurs invest a minimum amount of money in their start-ups (at least $€ 75,000$ in the case of Ireland). On a qualitative level, countries often require that entrepreneurs submit a business plan for evaluation, as in the case of Denmark and Spain. Some countries may even require that companies be endorsed by an official body (e.g., the United Kingdom's Home Office) or that founders show evidence of professional or commercial ties within the country (e.g., Sweden).

- Extent of ownership of the founding team: Countries typically require that petitioners own a minimum share of their company, with Sweden and Canada both requiring that founders own a controlling stake, but with Canada permitting a founding team of up to five.

- Qualifications of the entrepreneur: Countries often impose requirements around language proficiency, minimum levels of related experience, and/or minimum levels of educational attainment. For example, France seeks at least a master's degree or five years of professional work experience. Australia requires petitioners be under the age of 55 .

- Economic impact of the venture: In addition to requiring that the startup be located in their country, countries often screen ventures based on their economic impact. Sweden, for example, requires that startups produce and/or sell their services or goods within Sweden. Ireland requires evidence that a given start-up plan be "capable of creating 10 jobs in Ireland and realizing $€ 1$ million in sales within three to four years of starting up." Some countries offer preferential treatment to entrepreneurs who intend to build businesses within certain high-value sectors. New Zealand, for example, waives its minimum NZ\$100,000 (approxi-

gating the legal steps to start a company, or lack of capital to pilot projects), while others are generally focused on attracting more new businesses.

23. Sources for this section are given at the end of the chapter. An online appendix for the chapter describes country-level visa programs in greater detail. See S. P. Kerr and W. R. Kerr, "Immigration Policy Levers for US Innovation and Startups," NBER Appendix (Cambridge, MA: National Bureau of Economic Research), http://www.nber.org/data-appendix/c14424 /201118-KK-Appendix.pdf. 
mately US\$70,000) investment requirement for companies related to science, information and communications technology, or "other high value export-oriented sector." Thailand's start-up visa is specifically tailored to entrepreneurs operating within 13 priority industries such as "next-generation automotive," "smart electronics," "agriculture and biotechnology," and "food for the future."

- Financial self-sufficiency of the entrepreneur: Countries typically require that entrepreneurs show minimum personal assets. For example, Sweden requires SEK 200,000 (approximately US $\$ 23,000$ ) available for two years.

Countries differ on the terms and pathways to permanent residency and citizenship they offer to foreign entrepreneurs. Thailand's visa is renewable every two years, though it offers no obvious path to permanent residence. Similarly, Ireland issues entrepreneur visas with an initial validity period of two years, after which the visa may be extended for three years, then for five years. However, the Irish government expressly states that it "does not provide for preferential access to citizenship for successful applicants" of its start-up visa program. By contrast, Australia offers a path to permanent residence for entrepreneurs who demonstrate " 2 key success factors, or 1 key success factor and 3 supporting success factors." Examples of key success factors are employing two or more Australians, generating an annual turnover of at least AUD300,000 (approximately US\$228,000), and filing a provisional patent. Supporting success factors are more qualitative, such as "adapting [one's] entrepreneurial activities into other business areas" and "receiving formal awards or recognition."

Most host countries would like to attract successful entrepreneurs, yet half of start-ups fail within the first five years. As it is hard to predict which businesses will succeed, countries often admit immigrant entrepreneurs who look promising and then observe their success over the duration of their stay. These conditional visas can be renewed (or converted to a permanent residence permit) if the business remains successful within a few years. Australia, New Zealand, Ireland, Singapore, and the United Kingdom have established versions of this approach. It is important to recognize, however, a tension in making start-up visas conditional on success. Policy makers often dream of attracting start-ups with exceptional potential for employment growth and economic impact, but these exceptional outcomes involve lots of experimentation with ideas (Kerr, Nanda, and Rhodes-Kropf 2014). Making visas conditional on success may push immigrant founders toward less risky ventures until their permanent residency is established.

A related point of tension is regional distribution. Some countries, such as Canada, provide visa set-asides or other incentives for entrepreneurs to locate outside the most prominent technological or economic clusters. (These policies mirror the reduced investment requirements for a US EB-5 
visa if the investment is made into targeted employment areas. Regional policies are also frequent in employment visas.) These regional policies can serve to spread out the distribution of locations impacted by immigrant entrepreneurs, and they may be an important aspect of gaining political buy-in. It is possible, however, that constraining the spatial choices of entrepreneurs may lead to fewer start-ups pursuing high-scale growth outcomes that are often more easily pursued in prominent clusters.

\subsubsection{US Start-Up Visa Proposals}

Over the last decade, both Democrats and Republicans have introduced and supported approximately two dozen bills in both the House and Senate during every session of Congress in support of a start-up visa. Though the vast majority of bills have received bipartisan support, none have emerged successfully from committee, been approved by both chambers, and been enacted into law.

The spirit of most proposed bills is similar: to charge the Secretary of Homeland Security with authorizing a certain number of start-up visasoften 75,000 - to entrepreneurs who satisfy minimum requirements. Requirements typically include minimum ownership (either "significant ownership" or a controlling interest), minimum funding from qualifying investors or venture capitalists, and/or the ability to generate revenue and create full-time jobs within the United States. Some bills have also stipulated that entrepreneurs possess a minimum amount in assets or have an annual income exceeding a certain threshold above the federal poverty level. Some bills have required that entrepreneurs possess either an unexpired $\mathrm{H}-1 \mathrm{~B}$ visa or a master's degree in STEM or another relevant academic discipline from a US school. ${ }^{24}$

Shortly after the "Startup Act 3.0" act was introduced in the House and Senate in 2013, the Ewing Marion Kauffman Foundation published a study by Stangler and Konczal (2013) that estimated the job-creation impact of a start-up visa. When using the legislative minimum requirements and typical venture survival rates, the authors derived a lower bound, estimating that four-year-old start-ups would create nearly 500,000 new jobs after 10 years. If further assuming that half the start-up visa companies would be technology and engineering companies and their employment levels would grow beyond the minimum thresholds to reflect typical industry averages, the authors derived a larger estimate of 1.6 million new jobs. Given that their methodology did not model the potential of start-up visa companies to become high-growth, become high-scale, and positively impact innovation,

24. See Attracting and Retaining Entrepreneurs Act, S. 3510, 114th Congress, 2016, https:// www.congress.gov/bill/114th-congress/senate-bill/3510/text; StartUp Visa Act of 2011, S. 565, 112th Congress, 2011, https://www.congress.gov/bill/112th-congress/senate-bill/565 /text. 
GDP, and productivity, the Kauffman Foundation deemed its range "conservative" and "low-end."

In 2019, the "Startup Act" was introduced on a bipartisan basis within the Senate and then referred to committee. The bill sought to authorize the Secretary of Homeland Security to issue up to 75,000 "conditional immigrant" visas to entrepreneurs who register a new business, employ at least two full-time employees, and invest or raise at least $\$ 100,000$ in the business within the first year. For the following three years, entrepreneurs would be required to employ an average of at least five full-time employees in order to remove the conditional basis of their visa. ${ }^{25}$

\subsubsection{US Modifications Related to Start-Up Founders}

Although congressional proposals have failed to pass both the House and Senate, two recent reforms at the federal level influenced the potential vitality of US immigrant entrepreneurship: the "Matter of Dhanasar," and the International Entrepreneur Rule.

In December 2016, the USCIS's Administrative Appeals Office (AAO) published a decision titled the Matter of Dhanasar. The decision updated the USCIS's analytical framework for assessing eligibility for National Interest Waivers (NIWs), which permit immigrants to self-petition for a green card without an employer sponsor or related labor certification. Under a 1998 precedent, petitioners for a NIW under the EB-2 category had to demonstrate that (1) the petitioner's area of employment is of "substantial intrinsic merit," (2) any proposed benefit from the individual's endeavors will be "national in scope," and (3) the national interest would be adversely affected if a labor certification were required.$^{26}$ The 2016 revision was due in part to the belief that the "third prong was especially problematic for certain petitioners, such as entrepreneurs and self-employed individuals."

The updated criteria now require "(1) that the foreign national's proposed endeavor has both substantial merit and national importance; (2) that the foreign national is well positioned to advance the proposed endeavor; and (3) that, on balance, it would be beneficial to the United States to waive the requirements of a job offer and thus of a labor certification." In its decision, the AAO specifically noted that the first prong "may be demonstrated in a range of areas such as business, entrepreneurialism," among others. The decision also noted that the USCIS recognized "that forecasting feasibility or future success may present challenges to petitioners and USCIS officers,

25. See Startup Act, S. 328, 116th Congress, 2019, https://www.congress.gov/bill/116th -congress/senate-bill/328/text.

26. A labor certification is required to "certify to the USCIS that there are not sufficient U.S. workers able, willing, qualified and available to accept the job opportunity in the area of intended employment and that employment of the foreign worker will not adversely affect the wages and working conditions of similarly employed U.S. workers." See Employment and Training Administration, "Permanent Labor Certification," US Department of Labor, https:// www.foreignlaborcert.doleta.gov/perm.cfm. 
and that many innovations and entrepreneurial endeavors may ultimately fail, in whole or in part, despite an intelligent plan and competent execution" and that it did not "require petitioners to demonstrate that their endeavors are more likely than not to ultimately succeed." 27 Though not decided with the express intent of spurring US immigrant entrepreneurship, the ruling effectively reformulated the EB-2 NIW category into one that is now more favorable to aspiring immigrant entrepreneurs.

In January of 2017, the DHS, under the Obama administration, published the International Entrepreneur Rule, a rule permitting the DHS to extend a discretionary grant of parole lasting up to 30 months (2.5 years) to entrepreneurs. Entrepreneurs must (1) possess at least 10 percent ownership interest in a start-up created within the last five years, (2) have an active and central role in the operations and future growth of the entity, (3) have secured a minimum of $\$ 100,000$ from government grants or at least $\$ 250,000$ from a qualified US investor for the business, and (4) demonstrate evidence of substantial potential for rapid business growth or job creation. In July 2017 the DHS published a delay rule, and in May 2018 the department proposed to eliminate the rule "because the department believes that it represents an overly broad interpretation of parole authority, lacks sufficient protections for US workers and investors, and is not the appropriate vehicle for attracting and retaining international entrepreneurs." 28

\subsection{Conclusions}

Immigrants have played a substantial role in US invention and entrepreneurship over the last several decades (Kerr 2019a). Further growth in these forms of immigrant contributions will be challenging under the current US immigration structure due to numerical caps at key transition points, especially the H-1B program size and the country caps on the rate at which employment-based green cards are awarded. The United States also lacks a start-up visa comparable to those developed over the last decade by many peer countries. This chapter has reviewed several policy reforms that would likely alleviate these constraints and foster greater US invention and entre-

27. See Administrative Appeals Office, "Matter of DHANASAR, Petitioner," December 27, 2016, https://www.justice.gov/eoir/page/file/920996/download; US Citizenship and Immigration Services, "Employment-Based Immigration: Second Preference EB-2," updated December 2, 2020, https://www.uscis.gov/working-united-states/permanent-workers/employment -based-immigration-second-preference-eb-2.

28. See Department of Homeland Security, "International Entrepreneur Rule," Federal Register, January 17, 2017, https://www.federalregister.gov/documents/2017/01/17/2017-00481 /international-entrepreneur-rule; Department of Homeland Security, "International Entrepreneur Rule: Delay of Effective Date," Federal Register, July 11, 2017, https://www.federal register.gov/documents/2017/07/11/2017-14619/international-entrepreneur-rule-delay-of -effective-date; US Citizenship and Immigration Services, "International Entrepreneur Parole," updated May 25, 2018, https://www.uscis.gov/humanitarian/humanitarian-parole /international-entrepreneur-parole. 
preneurship going forward. Like all policy choices regarding immigration, these economic considerations are a single factor in larger political dynamics.

\section{Start-Up Visa Information:}

- Australia: https://immi.homeaffairs.gov.au/visas/getting-a-visa/visa -listing/business-innovation-and-investment-888/entrepreneur -stream\#Eligibility

- Canada: https://www.canada.ca/en/immigration-refugees -citizenship/services/immigrate-canada/start-visa/eligibility.html

- Denmark: https://www.nyidanmark.dk/en-GB/Applying/Work/Start -up $\% 20$ Denmark

- France: https://france-visas.gouv.fr/en_US/web/france-visas /international-talents-and-economic-attractiveness

- Ireland: http://www.inis.gov.ie/en/INIS/Guidelines\%20for\%20Start -up\%20Entrepreneur\%20Programme.pdf/Files/Guidelines\%20for $\% 20$ Start-up\%20Entrepreneur\%20Programme.pdf

- New Zealand: https://www.immigration.govt.nz/documents/forms -and-guides/inz1221.pdf

- Singapore: https://www.mom.gov.sg/passes-and-permits/entrepass /eligibility

- Spain: http://www.exteriores.gob.es/Consulados/CIUDADDEL $\mathrm{CABO/en/InformacionParaExtranjeros/Pages/Law-on-Visas-for}$ -Entrepreneurs.aspx

- Sweden: https://www.migrationsverket.se/English/Private -individuals/Working-in-Sweden/Self-employment.html

- Thailand: https://www.boi.go.th/index.php?page=detail_smart_visa

- United Kingdom: https://www.gov.uk/guidance/immigration-rules /immigration-rules-appendix-w-immigration-rules-for-workers\#part -w5-specific-requirements-start-up

\section{References}

Akcigit, U., S. Baslandze, and S. Stantcheva. 2016. "Taxation and the International Mobility of Inventors." American Economic Review 106 (10): 2930-81.

Akee, R. K. Q., D. A. Jaeger, and K. Tatsiramos. 2013. "The Persistence of SelfEmployment across Borders: New Evidence on Legal Immigrants to the United States." Economics Bulletin 33 (1): 126-37.

Anderson, S. 2020a. "H-1B Denials Remain High, Especially for IT Services Companies." Forbes, February 26. https://www.forbes.com/sites/stuartanderson/2020 /02/26/h-1b-denials-remain-high-especially-for-it-services-companies/.

2020b. "Court Invalidates Key Trump Administration H-1B Visa Policies."

Forbes, March 11. https://www.forbes.com/sites/stuartanderson/2020/03/11/court -invalidates-key-trump-administration-h-1b-visa-policies/. 
Anderson, S., and M. Platzer. 2006. American Made: The Impact of Immigrant Entrepreneurs and Professionals on U.S. Competitiveness. National Venture Capital Association Report.

Audretsch, D., and M. Feldman. 1996. "R\&D Spillovers and the Geography of Innovation and Production." American Economic Review 86: 630-40.

Azoulay, P., B. F. Jones, J. D. Kim, and J. Miranda. 2020. "Immigration and Entrepreneurship in the United States." NBER Working Paper No. 27778. Cambridge, MA: National Bureau of Economic Research.

Bengtsson, O., and D. Hsu. 2014. "Ethnic Matching in the U.S. Venture Capital Market.” Journal of Business Venturing 30 (2): 338-54.

Bernstein, S., R. Diamond, T. McQuade, and B. Pousada. 2019. "The Contribution of High-Skilled Immigrants to Innovation in the United States.” Working Paper. https://web.stanford.edu/ diamondr/BDMP_2019_0709.pdf.

Bird, K., and S. Turner. 2014. "College in the States: Foreign Student Demand and Higher Education Supply in the U.S." EdPolicyWorks Working Paper Series No. 23.

Bloom, N., J. Van Reenen, and H. Williams. 2019. "A Toolkit of Policies to Promote Innovation." Journal of Economic Perspectives 33 (3): 163-84.

Blume-Kohout, M. 2016. Imported Entrepreneurs: Foreign-Born Scientists and Engineers in U.S. STEM Fields Entrepreneurship. US Small Business Administration Report.

Borjas, G. 1986. "The Self-Employment Experience of Immigrants." Journal of Human Resources 21: 487-506.

Borjas, G., and K. Doran. 2012. "The Collapse of the Soviet Union and the Productivity of American Mathematicians." Quarterly Journal of Economics 127 (3): 1143-1203.

Bound, J., B. Braga, G. Khanna, and S. Turner. 2020. "A Passage to America: University Funding and International Students." American Economic Journal: Economic Policy 12 (1): 97-126.

Bound, J., M. Demiric, G. Khanna, and S. Turner. 2015. "Finishing Degrees and Finding Jobs: U.S. Higher Education and the Flow of Foreign IT Workers." In Innovation Policy and the Economy, vol. 15, edited by William Kerr, Josh Lerner, and Scott Stern, 27-72. Chicago: University of Chicago Press.

Bound, J., G. Khanna, and N. Morales. 2017. "Understanding the Economic Impact of the H-1B Program on the U.S.” NBER Working Paper No. 23153. Cambridge, MA: National Bureau of Economic Research.

Brown, J. D., J. S. Earle, M. J. Kim, and K.-M. Lee. 2019. "Immigrant Entrepreneurs and Innovation in the US High Tech Sector." Census Bureau Working Paper.

Buchardi, K., T. Chaney, T. Hassan, L. Tarquinio, and S. Terry. 2019. "Immigration, Innovation, and Growth." NBER Working Paper No. 27075. Cambridge, MA: National Bureau of Economic Research.

Carlino, G., and W. R. Kerr. 2015. "Agglomeration and Innovation.” In Handbook of Urban and Regional Economics, vol. 5, edited by G. Duranton, V. Henderson, and W. Strange, 349-404. Amsterdam: North-Holland.

Chung, W., and A. Kalnins. 2006. "Social Capital, Geography, and the Survival: Gujarati Immigrant Entrepreneurs in the U.S. Lodging Industry." Management Science 52 (2): 233-47.

Clark, K., and S. Drinkwater. 2000. "Pushed Out or Pulled In? Self-Employment among Ethnic Minorities in England and Wales." Labour Economics 7 (5): 603-28.

. 2006. "Changing Patterns of Ethnic Minority Self-Employment in Britain: Evidence from Census Microdata." IZA Discussion Papers 2495, Institute for the Study of Labor (IZA). 
Clemens, M. A. 2011. "Economics and Emigration: Trillion-Dollar Bills on the Sidewalk?" Journal of Economic Perspectives 25 (3): 83-106.

Decker, R., J. Haltiwanger, R. Jarmin, and J. Miranda. 2014. "The Role of Entrepreneurship in US Job Creation and Economic Dynamism." Journal of Economic Perspectives 28 (3): 3-24.

Depew, B., P. Norlander, and T. Sorensen. 2017. "Inter-Firm Mobility and Return Migration Patterns of Skilled Guest Workers." Journal of Population Economics 30 (2): 681-721.

Dimmock, S. G., J. Huang, and S. Weisbenner. 2019. "Give Me Your Tired, Your Poor, Your High-Skilled Labor: H-1B Lottery Outcomes and Entrepreneurial Success.” NBER Working Paper No. 26392. Cambridge, MA: National Bureau of Economic Research.

Docquier, F., R. Turati, J. Valette, and C. Vasilakis. 2020. "Birthplace Diversity and Economic Growth: Evidence from the US States in the Post-World War II Period." Journal of Economic Geography 20 (2): 321-54.

Doran, K., A. Gelber, and A. Isen. 2015. "The Effects of High-Skill Immigration on Firms: Evidence from H-1B Visa Lotteries.” NBER Working Paper No. 20668. Cambridge, MA: National Bureau of Economic Research.

Doran, K., and C. Yoon. 2019. "Immigration and Invention: Evidence from the Quota Acts.”Working Paper. https://www3.nd.edu/ kdoran/Doran_Quotas .pdf.

Fairlie, R. W. 2012. Immigrant Entrepreneurs and Small Business Owners, and Their Access to Financial Capital. US Small Business Administration Report.

_. 2013. "Minority and Immigrant Entrepreneurs: Access to Financial Capital." In International Handbook on the Economics of Migration, edited by A. F. Constant and K. F. Zimmermann, 153-75. Cheltenham, UK: Edward Elgar.

Fairlie, R. W., and M. Lofstrom. 2014. "Immigration and Entrepreneurship." In Handbook on the Economics of International Migration, edited by B. R. Chiswick and P. W. Miller, 877-911. Amsterdam: Elsevier.

Fairlie, R. W., and B. D. Meyer. 2003. "The Effect of Immigration on Native SelfEmployment." Journal of Labor Economics 21 (3): 619-50.

Fairlie, R. W., J. Zissimopoulos, and H. A. Krashinsky. 2010. "The International Asian Business Success Story: A Comparison of Chinese, Indian, and Other Asian Businesses in the United States, Canada, and United Kingdom." In International Differences in Entrepreneurship, edited by J. Lerner and A. Schoar, 179-208. Chicago: University of Chicago Press.

Fallick, B., C. Fleischman, and J. Rebitzer. 2006. "Job-Hopping in Silicon Valley: Some Evidence Concerning the Microfoundations of a High-Technology Cluster." Review of Economics and Statistics 88 (3): 472-81.

Feldman, M., and D. Kogler. 2010. "Stylized Facts in the Geography of Innovation." In Handbook of the Economics of Innovation, vol. 1, edited by B. Hall and N. Rosenberg, 381-410. Oxford: Elsevier.

Ghimire, K. 2018. "Supply of Immigrant Entrepreneurs and Native Entrepreneurship." Working Paper. https://ssrn.com/abstract=3248842.

Glaeser, E., S. P. Kerr, and W. R. Kerr. 2015. "Entrepreneurship and Urban Growth: An Empirical Assessment with Historical Mines." Review of Economics and Statistics 97 (2): 498-520.

Glennon, B. 2019. "How Do Restrictions on High-Skilled Immigration Affect Offshoring? Evidence from the H-1B Program.” NBER Working Paper No. 27538. Cambridge, MA: National Bureau of Economic Research.

Gompers, P. A., V. Mukharlyamov, and Y. Xuan. 2016. "The Cost of Friendship." Journal of Financial Economics 119 (3): 626-44. 
Goolsbee, A. 1998. "Does Government R\&D Policy Mainly Benefit Scientists and Engineers?" American Economic Review 88 (2): 298-302.

Haltiwanger, J., R. Jarmin, and J. Miranda. 2013. "Who Creates Jobs? Small vs. Large vs. Young." Review of Economics and Statistics 95 (2): 347-61.

Hart, D. M., and Z. J. Acs. 2011. "High-Tech Immigrant Entrepreneurship in the United States.” Economic Development Quarterly 25 (2): 116-29.

Hegde, D., and J. Tumlinson. 2014. "Does Social Proximity Enhance Business Relationships? Theory and Evidence from Ethnicity's Role in US Venture Capital." Management Science 60 (9): 2355-80.

Hira, R. 2010. "The H-1B and L-1 Visa Programs: Out of Control.” EPI Briefing Paper. Washington, DC: Economic Policy Institute.

Hunt, J. 2011. "Which Immigrants Are Most Innovative and Entrepreneurial? Distinctions by Entry Visa." Journal of Labor Economics 29 (3): 417-57.

- 2015. "Are Immigrants the Most Skilled US Computer and Engineering Workers?" Journal of Labor Economics 33 (S1): S39-77.

. 2017. "How Restricted Is the Job Mobility of Skilled Temporary Work Visa Holders?" NBER Working Paper No. 23529. Cambridge, MA: National Bureau of Economic Research.

Hunt, J., and M. Gauthier-Loiselle. 2010. "How Much Does Immigration Boost Innovation?" American Economic Journal: Macroeconomics 2 (2): 31-56.

Kahn, S., and M. MacGarvie. 2018. "The Impact of Permanent Residency Delays for STEM PhDs: Who leaves and Why." NBER Working Paper No. 25175. Cambridge, MA: National Bureau of Economic Research.

Kahn, S., G. Mattina, and M. MacGarvie. 2017. "Misfits, Stars, and Immigrant Entrepreneurship." Small Business Economics 49 (3): 533-57.

Kato, T., and C. Sparber. 2013. "Quotas and Quality: The Effect of H-1B Visa Restrictions on the Pool of Prospective Undergraduate Students from Abroad." Review of Economics and Statistics 95 (1): 109-26.

Kerr, S. P., and W. R. Kerr. 2013. "Immigration and Employer Transitions for STEM Workers." American Economic Review Papers and Proceedings 103 (3): 193-7.

_. 2017. "Immigrant Entrepreneurship." In Measuring Entrepreneurial Businesses: Current Knowledge and Challenges, edited by J. Haltiwanger, E. Hurst, J. Miranda, and A. Schoar, 187-249. Chicago: University of Chicago Press.

. 2020. "Immigrant Entrepreneurship in America: Evidence from the Survey of Business Owners 2007 \& 2012.” Research Policy 49 (3): 103918.

Kerr, S. P., W. R. Kerr, and W. F. Lincoln. 2015a. "Firms and the Economics of Skilled Immigration." In Innovation Policy and the Economy, vol. 15, edited by W. R. Kerr, J. Lerner, and S. Stern, 115-52. Chicago: University of Chicago Press. . 2015b. "Skilled Immigration and the Employment Structures of U.S. Firms." Journal of Labor Economics 33 (S1): S109-45.

Kerr, S. P., W. R. Kerr, Ç. Özden, and C. Parsons. 2016. "Global Talent Flows." Journal of Economic Perspectives 30 (4): 83-106.

2017. "High-Skilled Migration and Agglomeration." Annual Review of Economics 9: 201-34.

Kerr, W. R. 2008. "Ethnic Scientific Communities and International Technology Diffusion." Review of Economics and Statistics 90 (3): 518-37.

2010. "Breakthrough Inventions and Migrating Clusters of Innovation." Journal of Urban Economics 67 (1): 46-60.

. 2017. "U.S. High-Skilled Immigration, Innovation, and Entrepreneurship: Empirical Approaches and Evidence." In The International Mobility of Talent and Innovation: New Evidence and Policy Implications, edited by C. Fink and E. Miguelez, 193-221. Cambridge: Cambridge University Press. 
2019a. The Gift of Global Talent: How Migration Shapes Business, Economy and Society. Palo Alto, CA: Stanford University Press.

2019b. "The Gift of Global Talent: Innovation Policy and the Economy." In Innovation Policy and the Economy, vol. 20, edited by J. Lerner and S. Stern, 1-37. Chicago: University of Chicago Press.

Kerr, W. R., and W. F. Lincoln. 2010. "The Supply Side of Innovation: H-1B Visa Reforms and U.S. Ethnic Invention." Journal of Labor Economics 28 (3): 473-508.

Kerr, W. R. and M. Mandorff. 2015. "Social Networks, Ethnicity, and Entrepreneurship.” NBER Working Paper No. 21597. Cambridge, MA: National Bureau of Economic Research.

Kerr, W. R., R. Nanda, and M. Rhodes-Kropf. 2014. "Entrepreneurship as Experimentation." Journal of Economic Perspectives 28 (3): 25-48.

Kerr, W. R., and F. Robert-Nicoud. 2020. "Tech Clusters." Journal of Economic Perspectives 34 (3): 50-76.

Lewis, E., and G. Peri. 2015. "Immigration and the Economy of Cities and Regions." In Handbook of Urban and Regional Economics, vol. 5, edited by G. Duranton, V. Henderson, and W. Strange, 625-85. Amsterdam: North-Holland.

Lofstrom, M. 2002. "Labor Market Assimilation and the Self-Employment Decision of Immigrant Entrepreneurs." Journal of Population Economics 15 (1): 83-114.

Matloff, N. 2003. "On the Need for Reform of the H-1B Non-Immigrant Work Visa in Computer-Related Occupations." University of Michigan Journal of Law Reform 36 (4): 815-914.

Mayda, A. M., F. Ortega, G. Peri, K. Shih, and C. Sparber. 2018. "The Effect of the H-1B Quota on the Employment and Selection of Foreign-Born Labor." European Economic Review 108: 105-28.

Moretti, E. 2019. "The Effect of High-Tech Clusters on the Productivity of Top Inventors." Center for Economic Policy Research Working Paper 13992.

Moser, P., and S. San. 2020. "Immigration, Science, and Invention: Evidence from the Quota Acts." Working Paper. https://ssrn.com/abstract=3558718.

Moser, P., A. Voena, and F. Waldinger. 2014. "German Jewish Emigres and U.S. Invention." American Economic Review 104 (10): 3222-55.

Nathan, M. 2015. "Same Difference? Minority Ethnic Inventors, Diversity and Innovation in the UK." Journal of Economic Geography 15 (1): 129-68.

Ottaviano, G., and G. Peri. 2006. "The Economic Value of Cultural Diversity: Evidence from US Cities.” Journal of Economic Geography 6 (1): 9-44.

Patel, K., and F. Vella. 2013. "Immigrant Networks and Their Implications for Occupational Choice and Wages." Review of Economics and Statistics 95 (4): 1249-77.

Pathak, P. A., A. Rees-Jones, and T. Sönmez. 2020. "Immigration Lottery Design: Engineered and Coincidental Consequences of H-1B Reforms." NBER Working Paper No. 26767. Cambridge, MA: National Bureau of Economic Research.

Peri, G. 2007. "Higher Education, Innovation and Growth." In Education and Training in Europe, edited by G. Brunello, P. Garibaldi, and E. Wasmer, 56-70. Oxford: Oxford University Press.

- 2012. Rationalizing U.S. Immigration Policy: Reforms for Simplicity, Fairness, and Economic Growth. Brookings Institution Report.

Peri, G., K. Shih, and C. Sparber. 2015. "STEM Workers, H-1B Visas and Productivity in US Cities." Journal of Labor Economics 33 (S1): S225-55.

Porter, M. E., J. W. Rivkin, M. A. Desai, K. M. Gehl, W. R. Kerr, and M. Raman. 2019. A Recovery Squandered: The State of U.S. Competitiveness 2019. Harvard Business School Report. https://www.hbs.edu/competitiveness/Documents/a -recovery-squandered.pdf.

Roach, M., H. Sauermann, and J. Skrentny. 2020. "Are Foreign PhDs More Entre- 
preneurial? Entrepreneurial Characteristics, Preferences and Outcomes of Native and Foreign Science and Engineering PhD Students." In The Roles of Immigrants and Foreign Students in U.S. Science, Innovation, and Entrepreneurship, edited by I. Ganguli, S. Kahn, and M. MacGarvie, 207-28. Chicago: University of Chicago Press.

Roach, M., and J. Skrentny. 2019. "Why Foreign STEM PhDs Are Unlikely to Work for U.S. Technology Startups." Proceedings of the National Academy of Sciences 116 (34): 16805-10.

Ruiz, N., and J. M. Krogstad. 2018. "East Coast and Texas Metros Had the Most H-1B Visas for Skilled Workers from 2010 to 2016." Pew Research Center, March 29. https://www.pewresearch.org/fact-tank/2018/03/29/h-1b-visa-approvals-by -us-metro-area.

Samila, S., and O. Sorenson. 2011. "Venture Capital, Entrepreneurship and Economic Growth." Review of Economics and Statistics 93: 338-49.

Saxenian, A. 1999. Silicon Valley's New Immigrant Entrepreneurs. San Francisco: Public Policy Institute of California.

_ 2002. "Silicon Valley's New Immigrant High-Growth Entrepreneurs." Economic Development Quarterly 16: 20-31.

Schuetze, H. J., and H. Antecol. 2007. "Immigration, Entrepreneurship and the Venture Start-Up Process: The Life Cycle of Entrepreneurial Ventures." In International Handbook Series on Entrepreneurship, vol. 3, edited by S. Parker, 107-35. New York: Springer.

Sparber, C. 2018. "Choosing Skilled Foreign-Born Workers: Evaluating Alternative Methods for Allocating H-1B Work Permits." Industrial Relations 57 (1): 3-34.

Stangler, D., and J. Konczal. 2013. Give Me Your Entrepreneurs, Your Innovators: Estimating Employment Impact of a Startup Visa. Ewing Marion Kauffman Foundation Report.

Stephan, P., and S. Levin. 2001. "Exceptional Contributions to US Science by the Foreign-Born and Foreign-Educated." Population Research and Policy Review 20 (1): 59-79.

Wadhwa, V., A. Saxenian, B. Rissing, and G. Gereffi. 2007. America's New Immigrant Entrepreneurs. Durham, NC: Duke University Master of Engineering Management Program and UC Berkeley School of Information.

Yeaple, S. 2018. "The Innovation Activities of Multinational Enterprises and the Demand for Skilled Worker, Non-Immigrant Visas." In High-Skilled Migration to the United States and Its Economic Consequences, edited by G. Hanson, W. Kerr, and S. Turner, 41-70. Chicago: University of Chicago Press.

Zucker, L., M. Darby, and M. Brewer. 1998. "Intellectual Human Capital and the Birth of U.S. Biotechnology Enterprises." American Economic Review 88 (1): 290-306. 